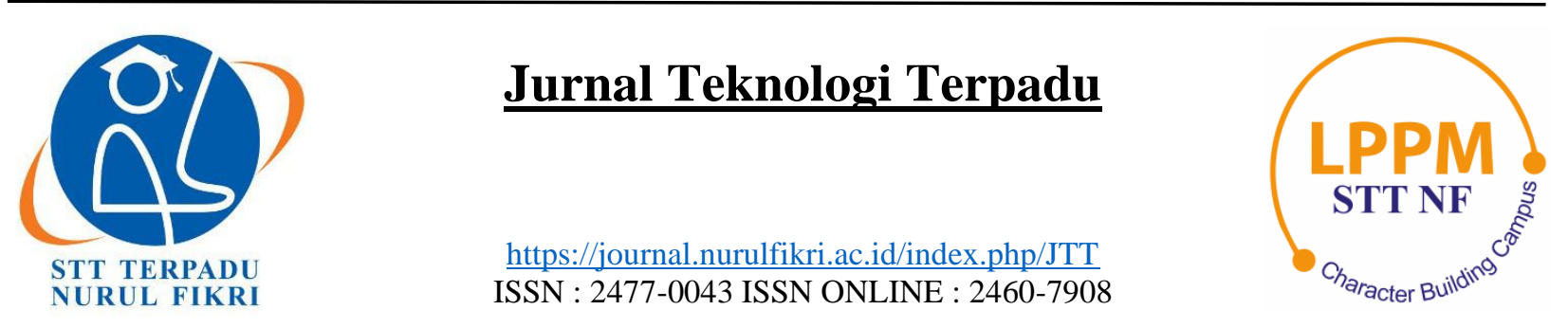

\title{
IMPLEMENTASI PENGHITUNG LAJU RESPIRASI PADA SISTEM POLISOMNOGRAFI MENGGUNAKAN MIKROFON DAN ARDUINO NANO
}

\author{
Martin Clinton Tosima Manullang ${ }^{1}$, Nova Resfita ${ }^{2}$ \\ ${ }^{1}$ Program Studi Teknik Informatika, Institut Teknologi Sumatera \\ ${ }^{2}$ Program Studi Teknik Biomedis, Institut Teknologi Sumatera \\ Lampung Selatan, Lampung, Indonesia 35365 \\ martin.manullang@ifi.itera.ac.id, nova.resfita@bm.itera.ac.id
}

\begin{abstract}
Sleep apnea is a severe sleep disorder leading to severe threats such as heart attacks, strokes, diabetes, kidney failure, hypertension, etc. Not only is the diagnosis of sleep apnea a challenging measure, but it also requires a high cost of equipment, the limitations of available tools, and becomes a complicated diagnosis operated personally at home. Using the microphone embedded in the Arduino Nano, a system to measure the respiratory rate develops as a minor part of the sleep apnea diagnostic system using polysomnography. A filtering system is attached to eliminate noise and environmental consequences around the observation site. This prototype evaluates by comparing the output value with the manual calculation of the respiratory rate. Of the trials executed, the achieved system accuracy in counting the respiratory rate is above $93 \%$, meaning that this prototype system is ideal as a method of measuring the respiratory rate.
\end{abstract}

Keywords: Sleep Apnea, Polysomnograph, Microphone, Arduino, Respiratory Rate

\begin{abstract}
Abstrak
Sleep Apnea merupakan kelainan ketika tidur yang memiliki berbagai dampak berbahaya bagi kesehatan serta dapat mengancam keselamatan seperti serangan jantung, stroke, diabetes, gagal ginjal, hipertensi dan sebagainya. Diagnosa sleep apnea menjadi tantangan di dunia medis, selain karena biaya peralatan yang mahal, keterbatasan alat yang ada, diagnosanya cukup rumit untuk dilakukan secara personal oleh masyarakat awam di rumah masing-masing. Dengan menggunakan mikrofon yang terdapat pada Arduino Nano, dirancanglah suatu sistem pengukuran laju pernapasan sebagai bagian kecil dari sistem diagnosa sleep apnea menggunakan polisomnografi. Pada sistem ini, sistem penapisan berlapis diimplementasikan untuk mengeliminasi derau akibat lingkungan sekitar tempat observasi. Purwarupa ini diuji dengan membandingkan nilai luarannya dengan perhitungan laju pernapasan secara manual. Berdasarkan pengukuran yang dilakukan, hasil akurasi yang dicapai bernilai diatas 93\%, yang berarti purwarupa sistem cukup ideal untuk digunakan sebagai metode pengukuran laju pernapasan.
\end{abstract}

Kata kunci: Sleep Apnea, Polisomnografi, Mikrofon, Arduino, Laju Respirasi

\section{PENDAHUluAN}

Sleep apnea adalah suatu kondisi tidur abnormal yang terjadi ketika pernapasan berhenti secara mendadak dan berulang-ulang tanpa disadari dan mengganggu siklus pernapasan selama tidur. Gangguan ini dapat menyebabkan kurangnya asupan oksigen ke otak dan organ tubuh lainnya sehingga dapat menyebabkan kondisi membahayakan seperti serangan jantung, stroke, gagal ginjal, diabetes, hingga kecelakaan ketika bekerja [1]. Secara medis, sleep apnea dideteksi dengan menggunakan suatu teknik bernama polisomnograf yang merupakan suatu metode yang digunakan oleh poligraf untuk memantau banyak variabel fisiologis secara terus menerus selama tidur (seperti pernapasan, detak jantung, dan aktivitas otot). Penggunaan layanan polisomnografi ini masih terbatas karena biaya yang tinggi sehingga menyebabkan banyak orang merasa enggan dan abai terhadap sleep apnea. Salah satu alasan yang menyebabkan biaya diagnosa yang mahal adalah harga alat yang sangat tinggi dan ketersediaan alat yang terbatas. Selain itu, metode diagnosa praktis untuk mendeteksi sleep apnea masih sukar ditemukan di pasaran [2].

Salah satu pengukuran yang dilakukan dalam polisomnografi adalah perhitungan jumlah respirasi dan henti nafas yang terjadi selama pasien tidur [3]. Jumlah respirasi menjadi penting untuk mendapatkan nilai rata-rata respirasi dalam satu menit (respiration rate). Sementara 
jumlah henti nafas dibutuhkan untuk mengukur tingkat keparahan dari sleep apnea. Semakin panjang durasi henti nafas dan kejadian yang terjadi dalam satu kali durasi tidur, maka semakin parah hasil diagnosa sleep apnea yang dialami oleh seorang pasien [4].

Dalam menentukan respiration rate dan jumlah henti nafas di tiap sesi tidur, ada beberapa metode yang digunakan. Salah satu yang paling sering digunakan dalam diagnosa sleep apnea adalah dengan menggunakan respiratory monitor [5]. Peralatan ini juga menjadi standar medis dalam mengukur respiratory rate pada pasien yang dirawat di unit gawat darurat maupun unit perawatan intensif (intensive care unit). Di sisi lain, ada beberapa metode alternatif dalam mengukur respiratory rate, misalnya dengan menggunakan gelombang ultrasonik yang diarahkan pada perubahan diafragma dada, maupun dengan menggunakan oximeter yang digunakan untuk mengukur saturasi oksigen di dalam tubuh [6]. Pada penelitian lain, sensor suhu juga kerap digunakan dalam menghitung laju pernapasan dengan mempertimbangkan perubahan signifikan per satuan waktu pada sensor yang ditempatkan di dekat hidung dan mulut [7].

Berdasarkan uraian metode akuisisi data laju pernapasan yang telah dilakukan, didapat suatu kesimpulan bahwa semuanya masih mengandalkan teknologi yang tinggi serta biaya yang relatif mahal. Oleh karena itu, perancangan serta pengembangan suatu metode perhitungan laju pernapasan yang efisien dan lebih minim biaya untuk dapat diimplementasikan dalam sistem polisomnografi menjadi berguna untuk meningkatkan kewaspadaan terhadap bahayanya sleep apnea.

Dalam penelitian ini, pengukuran laju respirasi akan diimplementasikan menggunakan mikrofon. Cara ini sedikit berbeda dengan metode pengukuran lainnya dikarenakan mikrofon umumnya digunakan untuk mencuplik sinyal suara, sementara mikrofon pada penelitian ini digunakan untuk mengukur laju respirasi. Metode ini menjadi bagian dalam akuisisi respiratory rate dan beberapa data lainnya untuk perancangan suatu sistem polisomnograf murah menggunakan Arduino yang dikembangkan untuk memenuhi kebutuhan diagnosa medis minim biaya.

Penelitian ini bertujuan untuk mengimplementasikan dan menguji hasil akuisisi dan perhitungan laju pernapasan dengan menggunakan mikrofon sebagai alat cuplik. Hasil dari penelitian ini diharapkan mampu menjadi solusi keterbatasan mendapatkan salah satu layanan polisomnografi yang ada saat ini serta keterkaitannya dengan implementasi suatu sistem polisomnografi yang akurat dan minim biaya. Purwarupa sistem diharapkan dapat bermanfaat bagi diagnosa dini serta pengembangan sistem tele-medicine yang memungkinkan pengukuran, diagnosa, serta perawatan dari jarak jauh dengan harga terjangkau.
Dalam pelaksanaannya, penelitian ini dibatasi untuk implementasi penghitung laju pernapasan dengan papan purwarupa Arduino Nano 33 BLE Sense yang telah dilengkapi dengan mikrofon yang terpasang di dalamnya.

\section{TINJAUAN PUSTAKA}

Penelitian ini melibatkan beberapa aspek pengembangan, metode dan perangkat. Pada bagian ini akan dijelaskan kajian terhadap poin-poin yang menjadi bagian dalam proses pengembangan sistem penghitung laju pernapasan dengan mikrofon.

\subsection{Sleep Apnea}

Sleep Apnea adalah gangguan tidur yang berpotensi serius di mana proses respirasi berulang kali terhenti hingga menyebabkan turunnya kadar oksigen dalam darah. Ciri umum sleep apnea adalah penderita yang mendengkur dengan keras serta terdengar nafas yang terhenti setelah menarik nafas. Sleep apnea terdiri atas beberapa jenis. Pertama, obstructive sleep apnea, yaitu bentuk yang lebih umum terjadi saat otot tenggorokan rileks dan menghambat aliran udara. Kedua, central sleep apnea, yang terjadi ketika otak tidak mengirimkan sinyal yang tepat ke otot yang mengontrol pernapasan. Ketiga, complex sleep apnea, juga dikenal sebagai central sleep apnea yang muncul akibat seseorang yang sedang mendapat pengobatan terkait pernapasan. Sleep apnea menjadi ancaman berbahaya karena dapat menyebabkan berbagai penyakit komplikasi seperti stroke hingga penyakit ko-morbid lain seperti diabetes, hipertensi, gagal ginjal, dan bahkan dapat menyebabkan kematian mendadak.

Cara untuk diagnosa sleep apnea diawali dengan melakukan pemeriksaan terhadap pasien melalui wawancara untuk mendata keluhan yang dialami pasien. Setelah pasien dianggap memiliki kemungkinan kuat mengidap sleep apnea maka diagnosa dilanjutkan dengan polisomnografi. Polisomnografi adalah suatu metode golden standard untuk mendiagnosa sleep apnea. Luaran dari polisomnografi adalah suatu indeks yang disebut sebagai Indeks ApneaHipopnea (AHI) yang menilai tingkat keparahan dari sleep apnea. AHI dihitung berdasarkan kalkulasi seluruh kejadian apnea yang muncul selama pasien tidur. Klasifikasi AHI dikategorikan dalam tiga bagian, yaitu:

- Derajat Ringan: Skor AHI 5 - 14

- Derajat Sedang: Skor AHI $15-29$

- Derajat Berat: Skor AHI > 30

\subsection{Polisomnografi}

Polisomnografi, juga disebut studi tidur, adalah tes yang digunakan untuk mendiagnosis gangguan tidur. Polisomnografi mencatat gelombang otak, kadar oksigen dalam darah, detak jantung dan laju pernapasan, serta gerakan mata dan kaki selama penelitian. Sistem pengukuran ini biasanya dilakukan di unit gangguan tidur di 
dalam rumah sakit atau di ahli gangguan tidur, dalam hal ini biasanya dilakukan oleh dokter spesialis THT. Tes ini mencatat pola tidur dan jumlah kejadian apnea yang dialami selama tidur. Polisomnografi melibatkan beberapa pengukuran dan instrumen yang secara simultan mengukur variabel-variabel vital selama tidur, diantaranya kadar oksigen dalam darah, denyut jantung serta rata-rata detak jantung tiap menit (dengan ECG), rotasi tubuh dan pergerakannya, laju pernapasan, hingga perubahan sinyal kelistrikan otak (EEG)

\subsection{Pengolahan Sinyal Suara}

Pemrosesan sinyal audio adalah bagian pada bidang pengolahan dan modulasi sinyal elektronik. Pemrosesan sinyal audio adalah area pemrosesan sinyal yang melibatkan operasi matematika dan pemrograman dalam menjalankan sistem pemrosesan. Sinyal audio merupakan representasi mekanis dari gelombang yang pemrosesannya terdiri dari kompresi dan normalisasi, tapis derau, hingga tapis frekuensi yang dapat memperbaiki kualitas sinyal suara [8]. Energi dalam sinyal audio diukur dalam satuan desibel. Kemudian, karena sinyal audio analog atau digital dapat diinterpretasikan, maka sinyal ini dapat diproses di domain waktu dan frekuensi. Prosesor analog bekerja pada sinyal analog secara langsung dan prosesor digital berjalan pada representasi digital dari sinyal analog secara matematis [9].

\subsection{Arduino}

Dalam penelitian ini, jenis mikrokontroler Arduino yang digunakan adalah Arduino Nano BLE Sense yang merupakan mikrokontroler berbasis nRF52840. Papan elektronika ini bekerja dengan tegangan operasi sebesar 3.3V dan clock speed $64 \mathrm{MHz}$. Papan ini memiliki flash memory sebesar $1 \mathrm{MB}$ dan SRAM sebesar 256KB. Perangkat ini juga memiliki mikrofon yang sudah tertanam di dalamnya, berjenis MP34DT05. Mikrofon ini merupakan omnidirectional device yang dapat menangkap suara dari lingkungan sekitar tanpa harus diarahkan pada sudut tertentu.

\subsection{Penelitian Terkait}

Dalam penelitian dan observasi yang dilakukan oleh William Daw, dkk [5], beberapa metode kontak dan nonkontak yang digunakan dalam pengukuran laju pernapasan dijabarkan secara jelas. Setidaknya hingga penelitian ini dipublikasikan pada tahun 2016, ada lima metode kontak dan enam metode non-kontak dalam melakukan perhitungan terhadap laju pernapasan. Beberapa metode kontak diantaranya adalah movement detection, pengukuran laju udara, metode akustik, menggunakan fungsi turunan dari elektrokardiografi (EKG), dan menggunakan fungsi turunan dari photoplethysomography (PPG). Sementara di ranah non kontak, beberapa metode tersebut diantaranya adalah dengan inframerah, data analisis video, deteksi kelembapan di dekat area pernafasan, radar, dan kamera telepon selular.

Di penelitian lain, Tim Fischer [10] melakukan penelitian untuk mengklasifikasikan pernafasan normal dan dengkuran dengan menggunakan telepon selular berbasis android. Sinyal suara terlebih dahulu ditapis (preprocessing) untuk memisahkan derau dari lingkungan rekam. Dengan menggunakan confusion matrix didapat nilai yang dapat menjadi tolok ukur klasifikasi antara dengkuran dan tarikan nafas normal.

Selain itu, pada penelitian yang dilakukan oleh Mahardika, dkk [11], dikembangkan suatu metode pengukuran laju pernapasan dengan memanfaatkan sensor suhu yang terhubung dengan mikrokontroller dan ponsel berbasis android. Sensor suhu yang digunakan bertipe LM-35. Sensor tersebut ditempatkan di dekat saluran pernapasan untuk mendeteksi perubahan suhu, dimana suhu pernapasan akan lebih tinggi ketika dihembuskan dibandingkan dengan suhu ruangan [12]. Perubahan ini kemudian dicatat untuk dihitung sebagai respirasi.

\section{METODE PENELITIAN}

Setelah mengulas referensi dan tinjauan studi yang ada, pada bagian ini akan dibahas metode untuk memenuhi tujuan penelitian.

\subsection{Tahapan Penelitian}

Penelitian ini memiliki tujuan akhir dalam mengembangkan suatu system, sehingga tahapan penelitian berikut disesuaikan untuk memenuhi tujuan dari penelitian berupa sebuah purwarupa sistem dan hasil uji kinerja dari sistem yang dikembangkan. Bagan urutan tahapan penelitian dapat dilihat pada bagan di bawah ini.

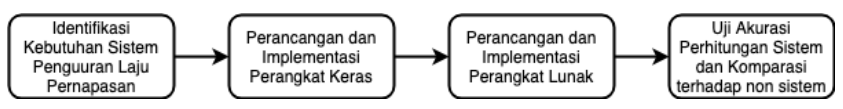

Gambar 1. Alur Penelitian dan Pengembangan

Inisiasi penelitian diawali dengan mengidentifikasi tujuan dari sistem dan parameter yang dibutuhkan. Setelah itu, dilanjutkan dengan merancang dan mengimplementasi perangkat keras dan perangkat lunak. Dalam tahap pengujian, akan dilakukan komparasi hasil luaran sistem dengan perhitungan secara manual dalam keterkaitannya dengan perhitungan laju pernapasan dan durasi apnea untuk menghasilkan sistem yang reliabel dan efektif serta efisien.

\subsection{Rancangan Alur Kerja Sistem}

Secara umum, polisomnografi bekerja ketika pasien yang sedang diobservasi berada dalam kondisi tidur. Sehingga, sistem harus diberikan trigger untuk memulai proses pencuplikan sinyal suara yang ada. Namun, sebelum sistem siap untuk merekam aktivitas respirasi tubuh, sistem terlebih dahulu melakukan kalibrasi terhadap ambang batas 
derau di lingkungan observasi. Setelah itu, sistem akan mulai bekerja 30 menit setelah trigger bahwa tidak ada aktivitas pergerakan tubuh yang terjadi.

Proses penapisan sinyal suara dilakukan secara bertahap, yaitu dimulai dengan aplikasi bandpass filter, kemudian diikuti dengan proses noise reduction dengan metode noise supressor untuk melakukan separasi antara derau lingkungan dengan proses respirasi.

Proses perhitungan respirasi dimulai dengan menghitung setiap amplitudo sinyal suara yang masuk dan memperbandingkannya dengan ambang batas (treshold). Apabila sinyal lebih besar dari ambang batas, maka akan dikategorikan sebagai inhale dan exhale secara berturutturut.

Pengelompokan apnea dilakukan apabila ditemukan suatu inhale yang berjarak lebh dari 4000ms dari exhale. Setiap terjadi keadaan apnea, sistem mencatat durasi tiap apnea dalam larik. Sistem mencatat jumlah sepasang inhale dan exhale dalam satu menit sebagai respiratory rate. Jika terjadi pergerakan, sistem akan kembali nonaktif. Rancangan alur kerja diatas dapat diamati pada bentuk diagram blok di bawah ini.

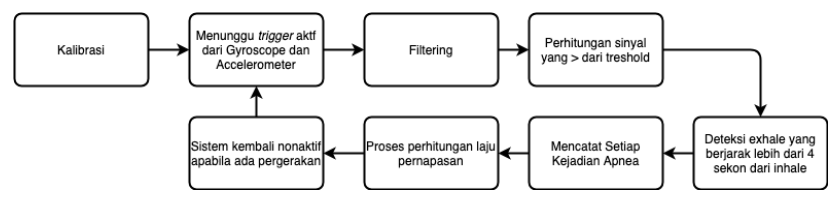

Gambar 2. Diagram Blok Sistem

\subsection{Rancangan Perangkat Keras}

Secara umum, penelitian ini hanya melibatkan satu buah perangkat keras yang terdiri atas mikrofon serta mikrokontroller terintegrasi dalam wujud Arduino Nano BLE Sense. Namun, dalam skala purwarupa, penelitian ini juga melibatkan beberapa sensor lain. Secara utuh, ruang lingkup pembatas antara penelitian ini dan purwarupa utuh sistem dapat dilihat pada diagram skematik di bawah ini.

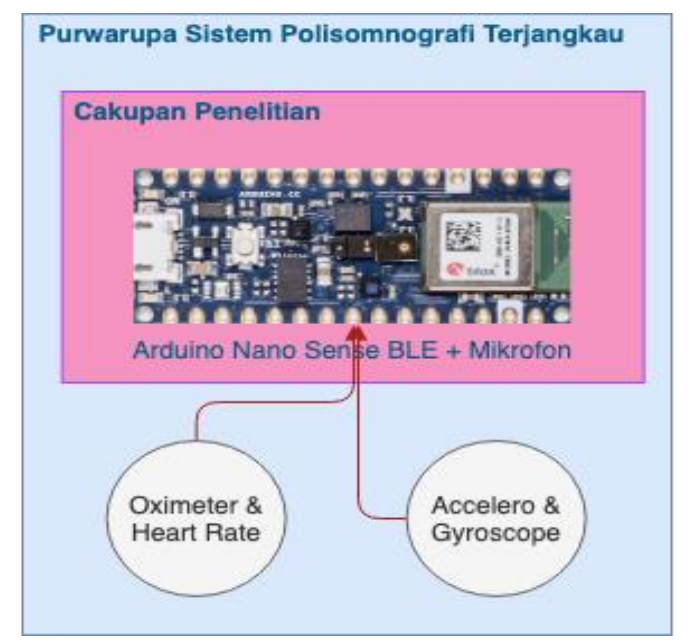

Gambar 3. Diagram Skematik

\subsection{Penapisan Berlapis}

Dalam implementasinya, data sinyal RAW yang dicuplik oleh mikrofon akan sangat tidak ideal apabila kondisi lingkungan observasi tidak mendukung, misalnya terdapat banyak suara yang dikategorikan sebagai noise. Untuk itu diperlukan beberapa tahapan penapisan (filtering step) untuk menghasilkan sinyal suara yang dapat merepresentasikan sinyal inhale dan exhale secara jelas.

Tapis pertama yang diterapkan berupa bandpass filter. Metode ini bertujuan untuk mengizinkan frekuensi dengan rentang 500-5000 $\mathrm{Hz}$ dapat lewat dan terekam di sistem. Dalam hal ini, filter menggunakan transformas Hilbert [11] dengan formula sebagai berikut:

$$
H(x(t))=\frac{1}{\pi} \int_{\infty}^{-\infty} x(\tau) \frac{1}{t-\tau} d \tau
$$

Setelah itu dilakukan proses tapis noise supressor. Adaptive noise supressor berbasis spectral supression digunakan untuk mereduksi derau yang ada. Setiap frame yang ada akan dikomparasikan dengan ciri noise yang ada. Setiap komponen spectral akan dibobotkan dengan formula [10] berikut:

$$
G(k, l)=\max \left(\frac{\operatorname{SNRPrio}(k, l)}{\operatorname{SNRPrio}(k, l)+1},-25 d B\right)
$$

Luaran dari proses penapisan berupa sinyal suara yang diperkuat namun minim derau.

\section{HASIL DAN PEMBAHASAN}

Pada tahapan pengujian, sistem dijalankan selama satu kali uji tidur berdurasi 3 jam dimana sistem disandingkan dengan mikrofon lain untuk kemudian dihitung nilai laju pernapasan, jumlah apnea dan rata-rata durasi apnea per tiap jam. Perhitungan sinyal suara secara manual dilakukan dengan perangkat lunak pengolah sinyal dan filter diterapkan menggunakan model matematika pada perangkat lunak tersebut.

Sinyal pada kondisi awal (raw signal) masih tidak ideal untuk dihitung karena masih mengandung derau dari lingkungan uji. Sinyal raw dapat dilihat pada gambar 4 di bawah ini.

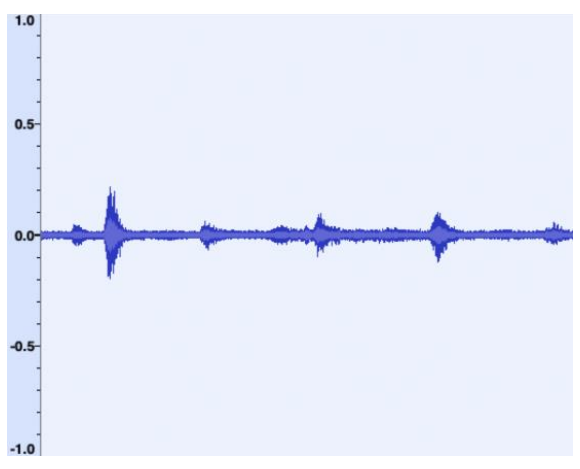

Gambar 4. Sinyal Raw pada saat Uji Coba 
Setelah dilakukan penapisan dengan rentang lebar 500-5000 $\mathrm{Hz}$, maka dihasilkan sinyal yang lebih spesifik dan terbebas dari noise frekuensi tinggi serta frekuensi sub low sebagaimana yang dapat dilihat pada gambar 5 .

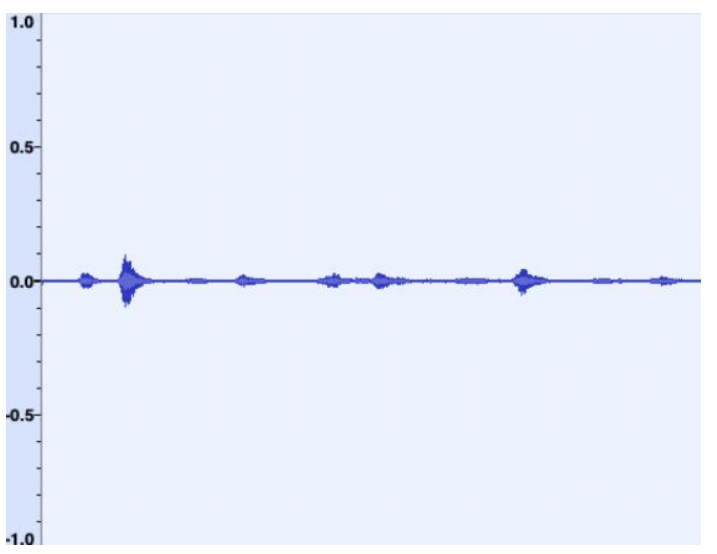

Gambar 5. Sinyal Hasil Bandpass

Dapat dilihat bahwa amplitudo pada sinyal setelah dilewatkan melalui tapis bandpass menjadi lebih kecil. Untuk itu dilakukan konversi dari skala -1 ke 1 menjadi skala dalam satuan desibel. Hasil yang didapat dapat dilihat pada gambar 6 .

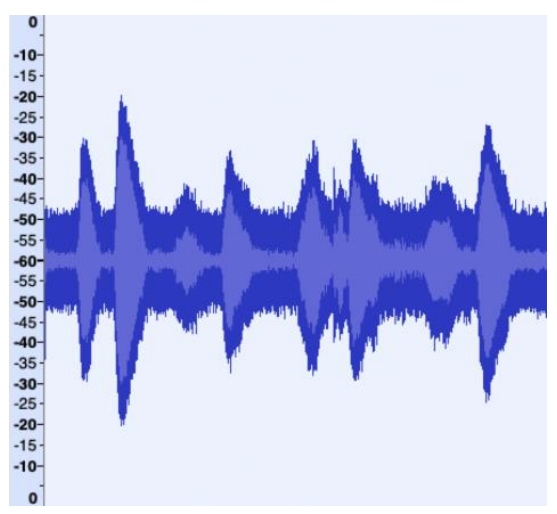

Gambar 6. Gambar Visualisasi Sinyal setelah Dikonversi ke Desibel

Tahap terakhir pada preprocessing sinyal adalah melakukan noise supressor untuk mereduksi noise dan mengambil puncak-puncak yang akan diidentifikasi sebagai inhale dan exhale. Gambar hasil noise supressor dapat diamati pada gambar 7.

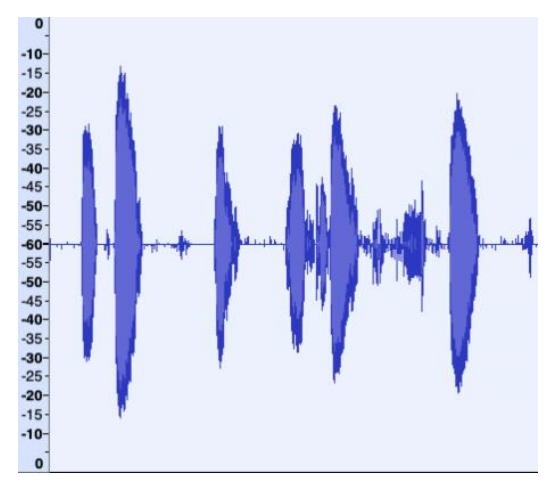

Gambar 7. Hasil Keluaran dari Proses Noise Supressor
Perhitungan secara manual dilakukan untuk menghitung jumlah inhale dan exhale di tiap jam. Proses memberikan label dapat diamati pada gambar di bawah ini.

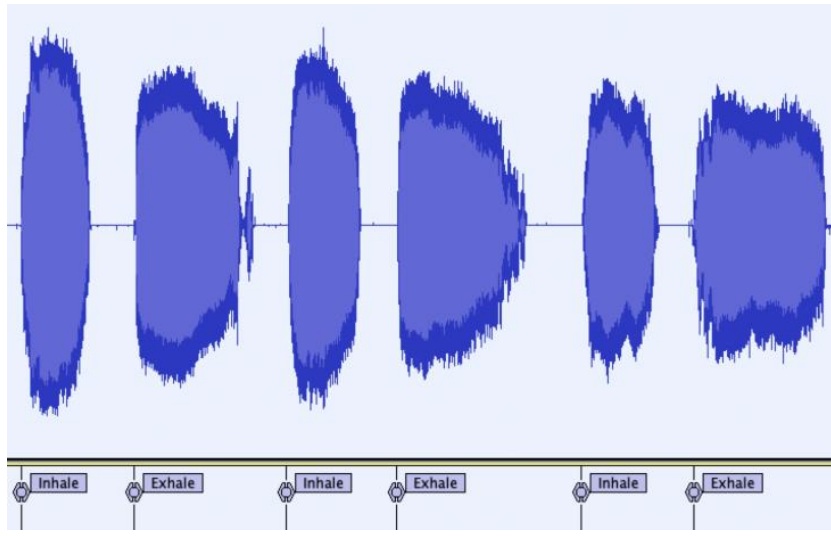

Gambar 8. Proses Label Inhale dan Exhale

Perhitungan laju respirasi didasarkan pada jarak antar exhale dalam satuan $m s$ dan dibagi dengan 60.000. Variabel respirasi akan diperbaharui secara berkala sesuai dengan jarak antar exhale.

$$
\text { Respiratory Rate }=\frac{\Delta \text { exhale }}{60000}
$$

Hasil komparasi jumlah perhitungan manual dan menggunakan sistem dapat dilihat pada tabel di bawah ini

Tabel 1. Perbandingan Perhitungan

\begin{tabular}{ccccc}
\hline Jam ke & $\begin{array}{l}\text { Jumlah } \\
\text { Inhale } \\
\text { Exhale } \\
\text { (Manual) }\end{array}$ & $\begin{array}{l}\text { Jumlah } \\
\text { Inhale } \\
\text { Exhale } \\
\text { (Sistem) }\end{array}$ & $\begin{array}{l}\text { Respirator } \\
\text { y Rate } \\
\text { Manual }\end{array}$ & $\begin{array}{l}\text { Respirator } \\
\text { y Rate } \\
\text { Sistem }\end{array}$ \\
\hline 1 & 840 & 902 & 14 & 15 \\
2 & 780 & 802 & 13 & 13,3 \\
3 & 800 & 818 & 13,3 & 13,6 \\
\hline
\end{tabular}

Berdasarkan tabel perhitungan respiratory rate yang dilakukan secara manual dan sistem yang dirancang, dapat diperoleh perhitungan respirasi pada tiap jam berturut-turut adalah $93 \%, 97 \%$, dan $98 \%$.

\section{KESIMPULAN}

Secara umum, penggunaan mikrofon yang terdapat pada arduino nano maupun mikrofon biasa memungkinkan dapat digunakan untuk mencuplik sinyal suara yang diinterpretasikan menjadi penghitung laju pernapasan. Pada penelitian ini, implementasi mikrofon yang terdapat pada microcontroller arduino nano menghasilkan perhitungan yang baik dan akurat dengan tingkat persentase diatas $93 \%$. Kemampuan mikrofon pada arduino nano beserta mikrokontroller sangat mumpuni untuk melakukan realtime processing. Teknologi penapisan dan perhitungan menjadi tantangan pengembangan, baik menggunakan filter digital, maupun melakukan perhitungan yang tidak berdasarkan treshold tetapi dengan aplikasi pembelajaran 
mesin untuk mengidentifikasi karakter suara pernafasan atau derau lingkungan.

\section{DAFTAR PUSTAKA}

[1] O. Kadarullah and Y. Annisa, "Pengaruh Obstructive Sleep Apnea (OSA) terhadap Terjadinya Hipertensi di Poli Saraf RSUD Prof. DR. Margono Soekarjo," Vol. XIII, No. 2, pp. 11-21, 2016 .

[2] V. Sterpenich, L. Perogamvros, G. Tononi, and S. Schwartz, "Experiencing Fear in Dreams Relates to Brain Responses to Aversive Stimuli During Wakefulness," Sleep Med., vol. 40, no. 2017, p. e259, 2017, doi: 10.1016/j.sleep.2017.11.759.

[3] M. A. Ciptaan and T. S. Hariyati, "Kemajuan Teknologi dalam menentukan Test Diagnostic serta Monitoring Terjadinya Sleep Apnea: Studi Literatur," Carolus J. Nurs., vol. 2, no. 1, pp. 52$62,2019$.

[4] L. Wang, Y. Lin, and J. Wang, "A RR Interval Based Automated Apnea Detection Approach using Residual Network," Comput. Methods Programs Biomed., vol. 176, pp. 93-104, 2019, doi: 10.1016/j.cmpb.2019.05.002.

[5] W. Daw, "Medical Devices for Measuring Respiratory Rate in Children: a Review," J. Adv. Biomed. Eng. Technol., vol. 3, no. 1, pp. 21-27, 2016, doi: 10.15379/2409-3394.2016.03.01.04.

[6] A. S. Grevtseva, K. J. Smirnov, V. V. Davydov, and V. Y. Rud, "Development of Methods for Results Reliability Raise During The Diagnosis of A Person's Condition by Pulse Oximeter," J. Phys. Conf. Ser., vol. 1135, no. 1, 2018, doi:
10.1088/1742-6596/1135/1/012056.

[7] R. Daňová, R. Olejnik, P. Slobodian, and J. Matyas, "The Piezoresistive Highly Elastic Sensor Based on Carbon Nanotubes for The Detection of Breath," Polymers (Basel)., Vol. 12, No. 3, p. 713, 2020, doi: 10.3390/polym 12030713 .

[8] H. Purwins, B. Li, T. Virtanen, J. Schlüter, S. Y. Chang, and T. Sainath, "Deep Learning for Audio Signal Processing," IEEE J. Sel. Top. Signal Process., vol. 13, no. 2, pp. 206-219, 2019, doi: 10.1109/JSTSP.2019.2908700.

[9] S. Das, J. Li, W. Dai, F. Metze, and S. Qu, "A Comparison of Deep Learning Methods for Environmental Sound Detection," IEEE Int. Conf. Acoust. Speech, Signal Process, 2017, vol. 10, no. 1, pp. 126-130, 2017.

[10] T. Fischer, J. Schneider, and W. Stork, "Classification of Breath and Snore Sounds using Audio Data Recorded with Smartphones in The Home Environment," IEEE Int. Conf. Acoust. Speech, Signal Process. 2016, pp. 226-230, 2016.

[11] I. K. E. G. Mahardika, T. Hamzah, T. Rahmawati, and L. Soetjiatie, "Measuring Respiration Rate Based Android," Indones. J. Electron. Electromed. Eng. Med. informatics, Vol. 1, No. 1, pp. 39-44, 2019, doi: 10.35882/ijeeemi.v1i1.7.

[12] S. S. Thomas, A. Saraswat, A. Shashwat, and V. Bharti, "Sensing Heart Beat and Body Temperature Digitally using Arduino," Int. Conf. Signal Process. Commun. Power Embed. Syst. SCOPES 2016 Proc., pp. 1721-1724, 2017, doi: 10.1109/SCOPES.2016.7955737. 